\title{
Dampak Covid terhadap Perekonomian secara Makro
}

\author{
Indri Arrafi Juliannisa ${ }^{(1)}$, \\ Nunuk Triwahyuningtyas ${ }^{(2)}$ \\ Charia Roswita ${ }^{(3)}$ \\ (1)(2)(3) Program Studi Ekonomi Pembangunan, Universitas Pembangunan Nasional Veteran Jakarta \\ Jl. RS. Fatmawati Raya, Pd. Labu, Kec. Cilandak, Kota Depok, Jawa Barat 12450. \\ e-mail: arrafi.juliannisa@gmail.com
}

\begin{tabular}{|l|l|l|}
\hline Diterima: 4 Desember 2020 & Direvisi: 13 Januari 2021 & Disetujui: 20 Januari 2021 \\
\hline
\end{tabular}

\begin{abstract}
The spread of the Corona virus that has spread to various parts of the world has an impact on the Indonesian economy, both in terms of trade, investment and tourism. In Indonesia, the spread of this virus began on March 2, 2020, many sectors of the economy were affected by this pandemic. Thousands of companies were forced to temporarily close to limit the spread of the virus. The government is trying to open several business sectors and continues to encourage SMEs to carry out online activities, but still in the regions and gradually increase tax revenue. The government has implemented various socio-economic policy programs, including incentive policies and tax facilities that can be utilized by taxpayers. The government has also provided a policy on interest rates and airplane ticket prices so that people are still interested in visiting several discount cities for tourist destinations due to the existence of Covid-19 which has greatly impacted the tourism sector. The crisis due to Covid-19 is currently occurring simultaneously, the impact is felt by vulnerable groups who are getting worse, including business groups that need mass crowds, groups of casual daily workers, street vendors, workers affected by layoffs, farmers, the community poor, ect.
\end{abstract}

Keywords: covid-19, indonesian economy, economic sector, slowing economic growth

\section{Pendahuluan}

Penyebaran virus Corona ini sangat cepat bahkan sampai ke lintas negara. Sampai saat ini terdapat 188 negara yang mengkorfirmasi terkena virus Corona. Penyebaran virus Corona yang telah meluas ke berbagai belahan dunia membawa dampak pada perekonomian Indonesia, baik dari sisi perdagangan, investasi dan pariwisata. Di Indonesia, penyebaran virus ini dimulai sejak tanggal 02 Maret 2020, seiring dengan berjalannya waktu, penyebaran covid-19 telah mengalami peningkatan yang signifikan (Hanoatubun, 2020). 
Tabel 1. Kasus dan kematian terkonfirmasi COVID-19 yang baru dilaporkan dan kumulatif, menurut Wilayah WHO, per 18 Oktober $2020 * *$

\begin{tabular}{|c|c|c|c|c|c|c|}
\hline \multirow[b]{2}{*}{ WHO Region } & & \multirow[b]{2}{*}{$\begin{array}{r}\text { Change in } \\
\text { new cases } \\
\text { in last } 7 \\
\text { days }\end{array}$} & \multirow[b]{2}{*}{$\begin{array}{r}\text { Cumulative } \\
\text { cases (\%) }\end{array}$} & \multirow[b]{2}{*}{$\begin{array}{r}\text { New deaths } \\
\text { in last } 7 \\
\text { days }(\%)\end{array}$} & \multirow{2}{*}{$\begin{array}{r}\text { Change in } \\
\text { new } \\
\text { deaths in } \\
\text { last } 7 \\
\text { days* }\end{array}$} & \multirow[b]{2}{*}{$\begin{array}{r}\text { Cumulative } \\
\text { deaths }(\%)\end{array}$} \\
\hline & $\begin{array}{c}\text { New cases in } \\
\text { last } \\
\text { days }(\%)\end{array}$ & & & & & \\
\hline Europe & $927.433(38 \%)$ & $25 \%$ & $8.027 .954(20 \%)$ & $\begin{array}{l}8.386 \\
(23 \%)\end{array}$ & $29 \%$ & $256.540(23 \%)$ \\
\hline Americas & $798.794(33 \%)$ & $-1 \%$ & $\begin{array}{c}18.800 .094 \\
(47 \%)\end{array}$ & $\begin{array}{l}16.283 \\
(45 \%)\end{array}$ & $-21 \%$ & $608.727(55 \%)$ \\
\hline $\begin{array}{c}\text { South-East } \\
\text { Asia }\end{array}$ & $513.444(21 \%)$ & $-11 \%$ & $8.546 .666(21 \%)$ & $\begin{array}{l}6.864 \\
(19 \%)\end{array}$ & $-11 \%$ & $135.275(12 \%)$ \\
\hline $\begin{array}{c}\text { Eastern } \\
\text { Mediterranean }\end{array}$ & $144.133(6 \%)$ & $4 \%$ & $2.786 .477(7 \%)$ & $\begin{array}{l}3.492 \\
(10 \%)\end{array}$ & $10 \%$ & $70.902(6 \%)$ \\
\hline Africa & $31.473(1 \%)$ & $11 \%$ & $1.267 .664(3 \%)$ & $\begin{array}{l}1.058 \\
(3 \%)\end{array}$ & $8 \%$ & $28.469(3 \%)$ \\
\hline $\begin{array}{l}\text { Western } \\
\text { Pacific }\end{array}$ & $28.317(1 \%)$ & $8 \%$ & $\begin{array}{c}688.737 \\
(2 \%)\end{array}$ & $\begin{array}{c}464 \\
(1 \%)\end{array}$ & $-27 \%$ & $14.823(1 \%)$ \\
\hline Other & - & - & $\begin{array}{c}741 \\
(<1 \%)\end{array}$ & - & - & $\begin{array}{c}13 \\
(<1 \%)\end{array}$ \\
\hline Global & $\begin{array}{c}2.443 .594 \\
(100 \%)\end{array}$ & $6 \%$ & $\begin{array}{c}40.118 .333 \\
(100 \%)\end{array}$ & $\begin{array}{c}36.547 \\
(100 \%)\end{array}$ & $-8 \%$ & $\begin{array}{c}1.114 .749 \\
(100 \%)\end{array}$ \\
\hline
\end{tabular}

Sumber: World Health Organization/WHO (2020)

Insiden kasus baru COVID-19 terus meningkat, sementara insiden kematian baru relatif stabil (Gambar 1). Per 18 Oktober, lebih dari 40 juta kasus dan 1,1 juta kematian telah dilaporkan secara global, dengan lebih dari 2,4 juta kasus baru dan 36.000 kematian baru dilaporkan selama seminggu terakhir. Jika dilihat terdapat tiga bagian wilayah yang memiliki proporsi besar terkait kasus Covid-19 yaitu wilayah Amerika, Eropa dan Asian Tenggara. Negara yang mencatat jumlah kasus baru mingguan tertinggi ialah Amerika Serikat, Brasil, Argentina, Kolombia, dan Meksiko, namun jika dibandingkan dengan wilayah Amerika, wilayah Eropa sendiri masih menunjukkan kenaikan kasus dan kematian tertinggi. Dimana Direktur Regional WHO untuk Eropa menyoroti bahwa wilayah tersebut saat ini melaporkan lebih dari tiga kali lebih banyak kasus per hari dibandingkan dengan puncak April, dengan penerimaan rumah sakit meningkat, meskipun jumlah kematian harian tetap lima kali lebih rendah daripada pada bulan April. Di wilayah Eropa ini sendiri negara yang mencatat jumlah kasus baru mingguan tertinggi ialah Prancis, Inggris Raya, Federasi Rusia, Republik Ceko dan Italia. Di wilayah Asia Tenggra jika dilihat secara keseluruhan, wilayah ini terus menunjukkan penurunan kasus dan kematian. Indonesia sendiri termasuk dalam wilayah ini yang mana per 18 Oktober 2020 tercatat total kasus Covid-19 sebanyak 365.240 kasus berdasarkan data (WHO, 2020). 
Jika dibandingkan antara pertumbuhan ekonomi saat lockdown dan saat new normal, tentu saja perkembangan nya akan berbeda. Dapat dikatakan bahwa saat diberlakukannya lockdown berada pada Quartal 2 (Q2). Badan Pusat Statistik (BPS) mencatat pertumbuhan ekonomi Indonesia kuartal II (Q2) 2020 mengalami kontraksi sebesar 5,32 persen year on year (yoy). Angka ini memburuk dari Q1 2020 yang mencapai 2,97 persen sehingga pertumbuhan ekonomi Indonesia diprediksikan dapat menghasilkan pertumbuhan minus (-). Tentu saja hal ini disebabkan karena adanya penerapan sistem lockdown sebagai upaya penekanan angka covid-19 di Indonesia (Thomas, 2020).

Tabel 2. Data Pertumbuhan Perekonomian di Beberapa Negara yang Terpapar Virus Covid19

(\% yoy)

\begin{tabular}{lrrrrrrrrrrr}
\hline GDP & $\mathbf{2 0 1 4}$ & $\mathbf{2 0 1 5}$ & $\mathbf{2 0 1 6}$ & $\mathbf{2 0 1 7}$ & $\mathbf{2 0 1 8}$ & $\mathbf{2 0 1 9}$ & $\mathbf{1 Q 2 0}$ & $\mathbf{2 Q 2 0 F}$ & $\mathbf{3 Q 2 0 F}$ & $\mathbf{4 Q 2 0 F}$ & $\mathbf{2 0 2 0 F}$ \\
\hline Growth & 2,6 & 2,9 & 1,5 & 2,3 & 2,9 & 2,3 & 0,3 & $-10,3$ & $-6,5$ & $-5,0$ & $-5,6$ \\
US & 1,3 & 2,1 & 1,8 & 2,4 & 1,8 & 1,2 & $-3,1$ & $-15,0$ & $-8,0$ & $-5,5$ & $-8,1$ \\
Euro Zone & 0,4 & 1,3 & 0,5 & 2,2 & 0,3 & 0,8 & $-1,7$ & $-8,8$ & $-6,1$ & $-3,1$ & $-4,9$ \\
Japan & 2,6 & 2,4 & 1,9 & 1,9 & 1,3 & 1,4 & $-1,7$ & $-19,9$ & $-9,9$ & $-6,3$ & $-8,8$ \\
UK & 7,4 & 7,0 & 6,8 & 6,9 & 6,7 & 6,1 & $-6,8$ & 1,9 & 5,0 & 6,0 & 1,8 \\
China & 3,2 & 2,8 & 2,9 & 3,2 & 2,7 & 2,0 & 1,4 & $-1,9$ & $-1,0$ & $-0,9$ & $-0,6$ \\
South Korea & 0,7 & $-2,0$ & 0,3 & 1,8 & 2,5 & 1,3 & 1,6 & $-9,9$ & $-5,6$ & $-4,1$ & $-5,0$ \\
Russia & 6,4 & 7,4 & 8,0 & 8,2 & 7,2 & 6,1 & 3,1 & $-18,9$ & $-4,4$ & 1,3 & 4,2 \\
India & 0,5 & $-3,5$ & $-3,3$ & 1,3 & 1,3 & 1,1 & $-0,3$ & $-11,7$ & $-6,7$ & $-5,5$ & $-6,5$ \\
Brazil & 5,0 & 4,9 & 5,0 & 5,1 & 5,2 & 5,0 & 3,0 & $-3,4$ & $-1,0$ & 1,4 & $-0,5$ \\
Indonesia & 6,0 & 5,1 & 4,5 & 5,7 & 4,7 & 4,3 & 0,7 & $-8,4$ & $-4,3$ & $-1,0$ & $-3,1$ \\
Malaysia & 1,0 & 3,1 & 3,4 & 4,1 & 4,2 & 2,4 & $-1,8$ & $-11,1$ & $-6,3$ & $-4,0$ & $-5,5$ \\
Thailand & 3,9 & 2,9 & 3,0 & 3,7 & 3,5 & 0,7 & $-0,7$ & $-12,6$ & $-6,0$ & $-3,6$ & $-5,7$ \\
Singapore & 6,2 & 6,1 & 6,9 & 6,7 & 6,2 & 5,9 & $-0,2$ & $-7,6$ & $-3,0$ & $-0,4$ & $-3,1$ \\
Philippines & & & & & & & & & \\
\hline
\end{tabular}

Sumber : Bank Mandiri (2020)

Pada Q1-Q4 2020 data diatas menjukkan fluktuasi dari pertumbuhan ekonomi negaranegara yang terdampak. Hal ini dikarenakan beberapa negara dan kota menerapkan pembatasan orang masuk dan keluar dari wilayah yang terindikasi mengalami wabah covid-19. Dilihat secara keseluruhan Inggris merupakan negara yang sangat terdampak dalam pertumbuhan ekonominya dilihat di Q2 pertumbuhan ekonominya sebesar -19,9\% yoy yang sebelumnya di Q1 masih sebesar $-1,7 \%$ yoy. Hal ini dikarenakan ribuan perusahaan terpaksa tutup sementara untuk membatasi penyebaran virus, sektor jasa yang dominan di Inggris yang membentuk sekitar 80 persen ekonomi tumbuh hanya 0,9 persen bulan April sehingga terjadi penurunan tingkat aktivitas dalam seni, hiburan dan rekreasi, serta di agen perumahan dan perusahaan IT (Lubis, 2020) .

Berdasarkan data komoditas minyak sawit (CPO), minyak, batubara, nikel dan aluminium adalah sektor yang terdampak Covid-19 hal ini dilihat dari fluktuatifnya harga rata-rata komoditas tersebut. Penurunan sektor industri dan pembangunan infrastruktur hal inilah yang adanya 
penurunan harga komoditas tembaga dan alumunium. Sedangkan untuk penurunan harga minyak sawit (CPO) terjadi karena adanya gangguan pasokan. Untuk harga minyak menurun di akibatkan karena dampak contaiment terhadap sektor transportasi dan risiko resesi ekonomi (Purnomo, 2020).

\begin{tabular}{|c|c|c|c|c|c|c|c|c|c|c|c|c|c|c|c|c|c|c|c|c|}
\hline \multicolumn{21}{|c|}{ Summary Proyeksi Harga Komoditas } \\
\hline & Spot Price & \multicolumn{3}{|c|}{ Harga Akhir Periode } & \multicolumn{4}{|c|}{ Harga Rata-rata } & \multicolumn{6}{|c|}{ Prediksi Harga Rata-rata 2020} & \multicolumn{6}{|c|}{ Prediksi Harga Rata-rata 2021} \\
\hline Commodity & $\begin{array}{l}\text { Jul 13, } \\
2020\end{array}$ & 2017 & 2018 & 2019 & 2017 & 2018 & 2019 & $2020 y t d$ & $\begin{array}{c}\text { OCE } \\
\text { F'Cast }\end{array}$ & $\begin{array}{c}\text { Bloom } \\
\text { Consen } \\
\text { (Jul-Sep } \\
2019 \text { ) }\end{array}$ & $\begin{array}{c}\text { Bloom } \\
\text { Consen } \\
\text { (Oct- } \\
\text { Dec } \\
2019 \text { ) }\end{array}$ & $\begin{array}{c}\text { Bloom } \\
\text { Consen } \\
\text { (Jan- } \\
\text { Mar } \\
2020 \text { ) }\end{array}$ & $\begin{array}{c}\text { Bloom } \\
\text { Consen } \\
\text { (Apr- } \\
\text { Jul } 13 \\
2020 \text { ) }\end{array}$ & $\begin{array}{c}\text { Fwd } \\
\text { Price } \\
\text { EOP (Jul } \\
13 \\
2020)\end{array}$ & $\begin{array}{c}\text { OCE } \\
\text { F'cast }\end{array}$ & $\begin{array}{c}\text { Bloom } \\
\text { Consen } \\
\text { (Jul-Sep } \\
2019 \text { ) }\end{array}$ & $\begin{array}{c}\text { Bloom } \\
\text { Consen } \\
\text { (Oct-Dec } \\
\text { 2019) }\end{array}$ & $\begin{array}{l}\text { Bloom } \\
\text { Consen } \\
\text { (Jan-Mar } \\
2020)\end{array}$ & $\begin{array}{c}\text { Bloom } \\
\text { Consen } \\
\text { (Apr-Jul } \\
13 \\
2020)\end{array}$ & $\begin{array}{c}\text { Fwd Price } \\
\text { EOP (Jul } \\
13 \\
2020)\end{array}$ \\
\hline $\begin{array}{l}\text { Oil (Brent) } \\
\text { USD/bbl }\end{array}$ & 42.7 & 66.9 & 53.8 & 66 & 54.8 & 71.7 & 64.2 & 42.2 & 42.7 & 61.6 & 62.2 & 43.3 & 39.9 & 43.4 & NA & 62.5 & 63.8 & 53 & 47.2 & 45.8 \\
\hline $\begin{array}{l}\text { CPO* (FOB } \\
\text { Malaysia) } \\
\text { USD/Ton }\end{array}$ & 582.2 & 601.8 & 484.8 & 743.4 & 647.7 & 559.5 & 529.9 & 585.8 & 521 & 513.9 & 526.9 & 540 & 62.8 & 557 & NA & 535.7 & 543.7 & 563.4 & 608.4 & 585.8 \\
\hline $\begin{array}{l}\text { Coal (New } \\
\text { Castle) }\end{array}$ & 52.2 & 100.8 & 102.1 & 67.7 & 88.1 & 107.2 & 78 & 61.1 & 59.4 & 70.2 & 75 & 70.8 & 61.3 & 60.2 & NA & 73.3 & 80 & 70.4 & 58.9 & 69.4 \\
\hline $\begin{array}{c}\text { Gold } \\
\text { (USD/Troy } \\
\text { Ounce }\end{array}$ & 1,803 & 1,309 & 1,281 & 1,517 & 1,258 & 1,269 & 1,394 & 1,657 & NA & 1,494 & 1,479 & 1,558 & 1,696 & 1,830 & NA & 1,514 & 1,528 & 1,600 & 1,758 & 1,858 \\
\hline $\begin{array}{l}\text { LME Nickel } \\
\text { Price } \\
\text { (USD/Ton) }\end{array}$ & 13,711 & 12,714 & 10,623 & 14,025 & 10,420 & 13,127 & 13,970 & 12,589 & NA & 14,686 & 15,261 & 12,900 & 12,750 & 13,749 & NA & 15,500 & 15,574 & 14,250 & 1,409 & 13,953 \\
\hline $\begin{array}{l}\text { LME } \\
\text { Alumunium } \\
\text { (USD/Ton) }\end{array}$ & 1,690 & 2,258 & 1,823 & 1,810 & 1,968 & 2,112 & 1,813 & 1,623 & NA & 1,843 & 1,820 & 1,741 & 1,594 & 1,702 & NA & 1,898 & 1.871 & 1,828 & 1,650 & 1,772 \\
\hline
\end{tabular}

Gambar 1. Perkembangan Sektor-Sektor Ekonomi di IndonesiaSelama Pandemi Covid -19 Sumber: Bloomberg, OCE *USDMYR = 4,26

Dibandingkan dalam sektor perdagangan emas, data menunjukkan kenaikan yang besar di harga perkiraan tahun 2020 ytd sebesar US\$1.830/troys ons. Bahkan prediksa harga rata-rata tahun 2021 juga menunjukkan angka yang terus konstan meningkat. Hal inilah yang telah membuat bisnis emas digemari karena banyak masyarakat menilai harga emas lebih stabil di saat pandemi ini. (Novika, 2020).

Dampak covid-19 terhadap perekonomian lainnya, misalnya pajak, kini pemerintah berupaya untuk membuka beberapa sektor usaha dan terus mendorong UKM untuk melakukan kegiatan secara online, namun tetap pada pemantauan dan secara bertahap guna meningkatkan penerimaan pajak. Untuk itu pelaku UKM disarankan untuk memanfaatkan kebijakan perpajakan di dalam PMK Nomor 44/PMK.03/2020 tentang Insentif Pajak untuk Wajib Pajak Terdampak Pandemi Covid-19 memberikan beberapa insentif pajak, diantaranya PPh Pasal 21 Ditanggung Pemerintah (DTP) untuk pekerja berpenghasilan bruto tidak lebih dari Rp.200 juta per tahun, PPh Final UMKM DTP, pembebasan PPh Pasal 22 Impor, pengurangan angsuran PPh Pasal 25 sebesar 30 persen dan restitusi Pajak Pertambahan Nilai (PPN) dipercepat (Kumala \& Junaidi, 2020).

Gambar 2 menunjukkan tingkat pengangguran terbuka ini meningkat sangat drastis. Hal ini cukup memprihatinkan sebagaimana kita lihat bahwa pada tahun 2018 dan 2019 presentase tingkat pengangguran terbuka di Indonesia menunjukkan hasil yang baik dibandingkan tahun-tahun sebelumnya. Berdasarkan data dari Badan Pusat Statistik (BPS) tingkat pengangguran terbuka di 
Indonesia pada tahun 2020 bulan Februari tercatat sebesar 05,01 persen. Berdasarkan data Kementerian Tenaga Kerja (Kemenaker), sejumlah 212.394 pekerja dari sektor formal terkena PHK, pekerja formal yang dirumahkansejumlah1.205.191 orang. Dari sektor nonformal, Kemenaker mencatat sekitar 282 ribu orang tidak memiliki penghasilan. (Indayani \& Hartono, 2020).

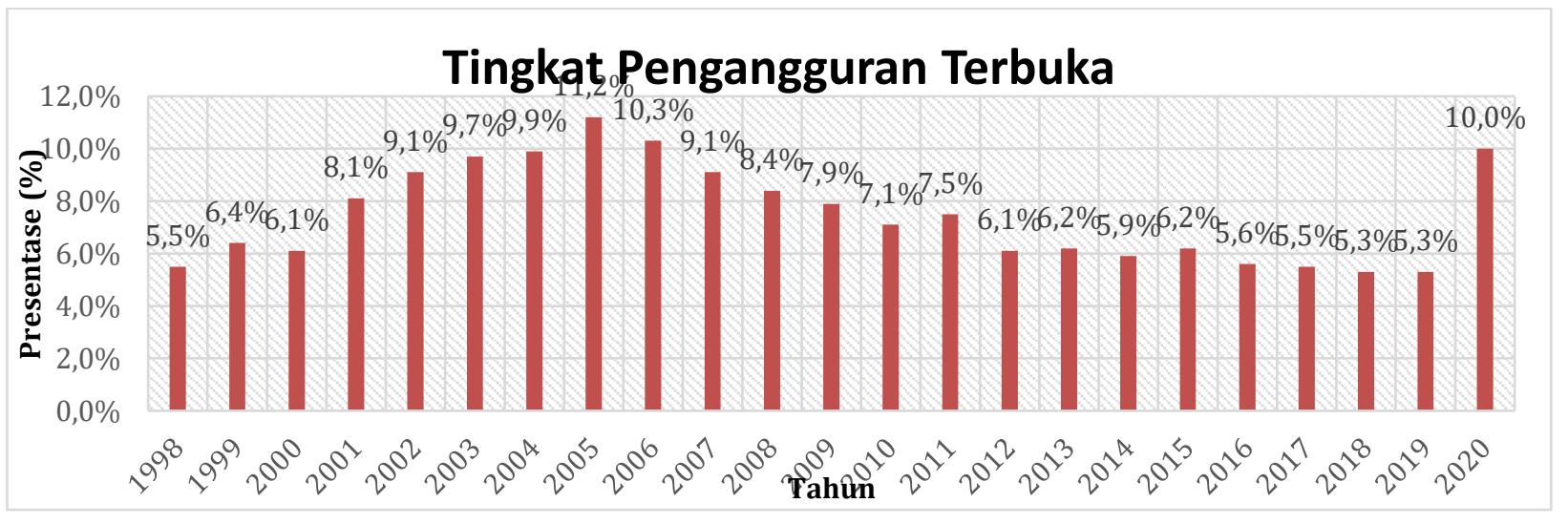

Gambar 2. Jumlah Tingkat Pengangguran Terbuka di IndonesiaSelama Pandemi Covid-19. Sumber: Badan Pusat Statistik/ BPS (2020)

\section{Telaah Literatur dan Kajian Pustaka}

Penelitian ini sangat erat dengan teori ekonomi baru yang menjelaskan model pertumbuhan endogen, teori pertumbuhan ekonomi baru dikembangkan oleh Robert Lucas dan Paul Romer. Teori ini memusatkan siklusnya pada sumber daya manusia yang menjadi modal utama peningkatan produksi dan ekonomi nasional. Menurut Lucas dan Romer, tenaga kerja yang memiliki wawasan luas, pendidikan tinggi, dan pelatihan profesional bisa mempercepat perkembangan industri dan teknologi. Sebagai hasilnya, kegiatan produksi nasional pun dapat ditingkatkan dengan lebih cepat. Pertumbuhan ekonomi adalah peningkatan produksi barang dan jasa selama periode tertentu. Pertumbuhan ekonomi menciptakan lebih banyak keuntungan bagi bisnis. Akibatnya, harga saham naik. Itu memberi perusahaan modal untuk berinvestasi dan mempekerjakan lebih banyak karyawan. Ketika lebih banyak pekerjaan diciptakan, pendapatan meningkat. Konsumen memiliki lebih banyak uang untuk membeli produk dan layanan tambahan (Amadeo, 2020).

Berdasarkan penelitian terdahulu, menurut Telaumbanua (2020), ia mengatakan bahwa Indonesia sebagai negara hukum, maka pencegahan terhadap jenis penyakit menular tersebut wajib dibentuk dalam sebuah aturan atau regulasi. Berdasarkan analisis penulis, ada 5 Peraturan Pemerintah yang wajib dibentuk dalam rangka melakukan tindakan penanggulangan dan pencegahan ancaman penyakit yang mudah menular seperti Covid19 dan ada 11 Peraturan Menteri 
Kesehatan terkait yang wajib dibentuk dalam rangka mengantisipasi ancaman Covid-19. Kedua jenis peraturan tersebut sangat berguna dalam hal mengantisipasi kedaruratan kesehatan yang pada akhirnya menjurus pada kekarantinaan kesehatan masyarakat Indonesia. Kiranya kedua jenis peraturan ini segera dibuat dalam rangka memberi kepastian hukum dalam mencegah menularnya Covid-19 secara meluas.

Dari hasil penelitian lain yang dilakukan oleh Pakpahan ( 2020), ia menjelaskan tentang Pandemi COVID-19 memberikan implikasi ekonomi, sosial, dan politik tidak saja negaranegara besar akan tetapi hamper seluruh negara di dunia. Rasanya tidak ada satu negarapun yang tidak terdampak pandemic COVID-19 saat ini. Indonesia adalah salah satu negara yang terdampak terutama pada sisi ekonomi. Indonesia yang didominasi oleh Usaha Mikro, kecil, dan Menengah (UMKM) perlu memberikan perhatian khusus terhadap sektor ini karena kontribusi UMKM terhadap pereknomian nasional yang cukup besar.

\section{Metode Penelitian}

Penelitian ini menggunakan pendekatan dan metode kualitatif, dengan jenis penelitian deskriptif dan ekploratif. Teknik pengumpulan data yang digunakan adalan focus group discussion (FGD) dan wawancara mendalam terhadap pihak narasumber sebanyak 2 orang yang berasal dari Bank Mandiri Syariah yaitu senior analis dan dari BPS, Kasubdit Statistik Industri Besar dan Sedang, konsep FGD adalah narasumber melakukan pemaparan sebanyak 2x dalam 2 hari yang berbeda, selanjutkan diadakan sesi tanya jawab atau diskusi terkait pokok bahasan masalah. Meskipun penelitian ini adalah penelitian kualitatif, tetapi jenis data yang dikumpulkan tidak terbatas pada data kualitatif yang digunakan untuk menjelaskan fenomena kemitraan dan acuan regulasi, tapi juga data statistik dan peta yang digunakan untuk menunjukkan bukti-bukti ekonomi secara empirik.

\section{Hasil Penelitian dan Pembahasan}

Penerapan pembatasan pembatasan sosial berskala besar (PSBB) memberikan dampak kepada beberapa sektor perekonomian prompt manufacturing index (PMI) ini cukup stabil karena adanya perbaikan yang terjadi pada seluruh komponen pembentuk PMI dengan indeks tertinggi. Pada triwulan IV-2020, volume produksi diprakirakan juga masih terus membaik walaupun masih terbatas karena hal tersebut sejalan dengan ekspektasi aktivitas industri yang membaik, selain itu dalam indikator pembentuk PMI salah satunya adalah volume pesanan barang input juga membaik hal dikarenakan adanya PSBB transisi sehingga mendorong meningkatnya aktivitas perekonomian dan kinerja perusahaan di sektor Industri Pengolahan. (Buchori \& Fardaniah, 2020). 

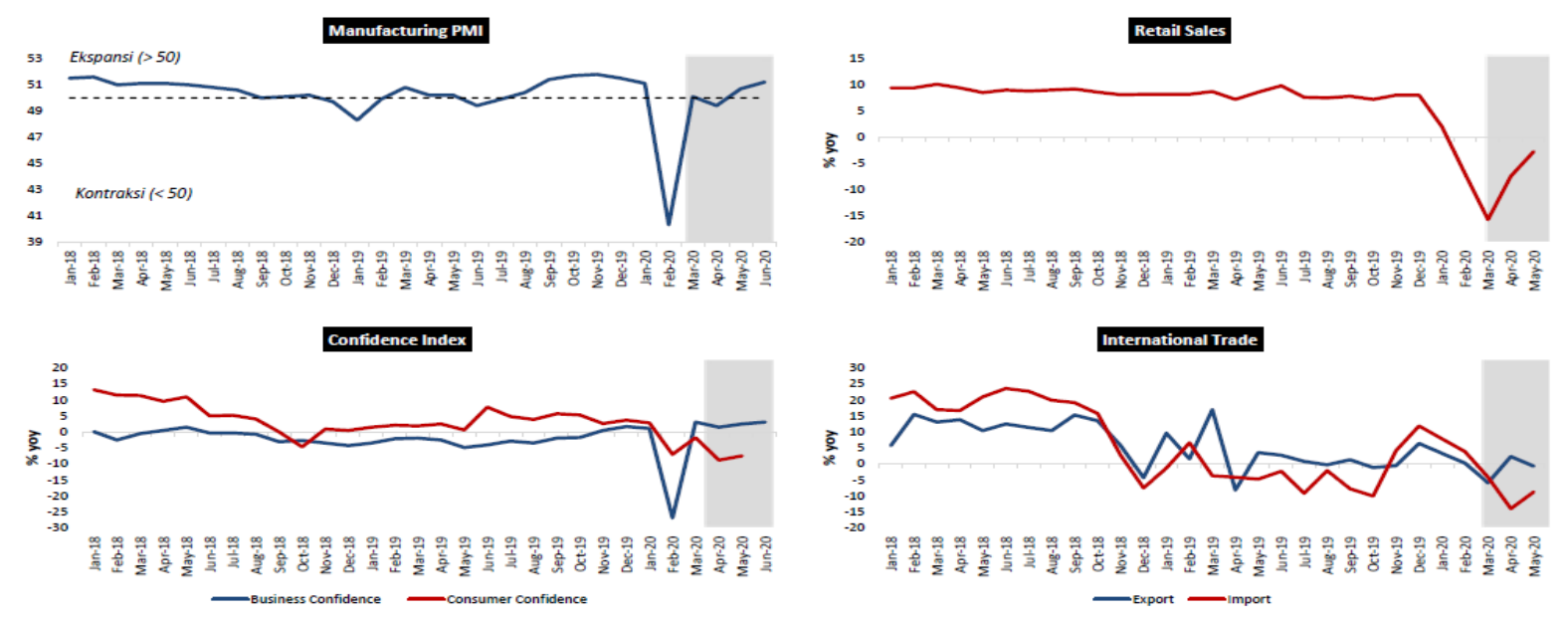

Gambar 3. Dampak Penerapan PSBB terhadap Sektor Manufacturing, Retail Sales, Confidence Index, dan International Trade.

Sumber: Badan Pusat Statistik/BPS (2020)

Pada sektor retail sales, Asosiasi Pengusaha Retail Indonesia (Aprindo) memperkirakan pertumbuhan industri retail sepanjang kuartal kedua 2020 terkontraksi minus 2,5 hingga $3 \%$ dibandingkan periode sebelumnya. Hal itu disebabkan oleh menurunnya daya beli masyarakat akibat pandemi. Pemasukan industri retail pun sedikit tertekan akibat timbulnya biaya tambahan untuk menjalankan protokol kesehatan di pertokoan, hingga kondisi keuangannya kembali stabil lantaran tak mampu menanggung biaya operasional. Sehingga pada akhirnya, bisnis retail menjadi terdampak karena adanya PSBB yang diberlakukannya disaat pandemi ini (Yunianto, 2020).

Dalam confidence index terdapat dua bahasan yaitu dari segi business confidence index dan consumer confidence index. Dampak dari PSBB ini bagi businness confidence index atau yang disebut indek kepercayaan bisnis mengalami penurunan. Hal ini disebabkan karena skor daya beli dan ekonomi global. Ketimbang kuartal sebelumnya (kuartal III), skor daya beli hanya naik 1,37\% atau 0,04 poin. Sebab itulah yang membuat keyakinan daya beli para CEO melorot 3\%. Sedangkan dari segi consumer confidence index, keyakinan konsumen terhadap kondisi ekonomi saat ini berkontraksi naik turun. Indeks keyakinan konsumen yang menurun dikarenakan penghasilan dan pembelian barang tahan lama yang turun (BI, Survei Konsumen Juli 2020 : Keyakinan Konsumen Terus Membaik, 2020).

Mitigasi pandemi Covid-19 juga menimbulkan disrupsi yang kuat pada tatanan perdagangan internasional. Dari sisi penawaran (supply), kebijakan lockdown dan working from home mengakibatkan berkurangnya tenaga kerja yang terlibat dalam aktifitas produksi. Kebijakan ini juga mengharuskan pemerintah untuk menutup pelabuhan air dan udara yang menghambat distribusi barang antar negara (Effendi, 2020). 


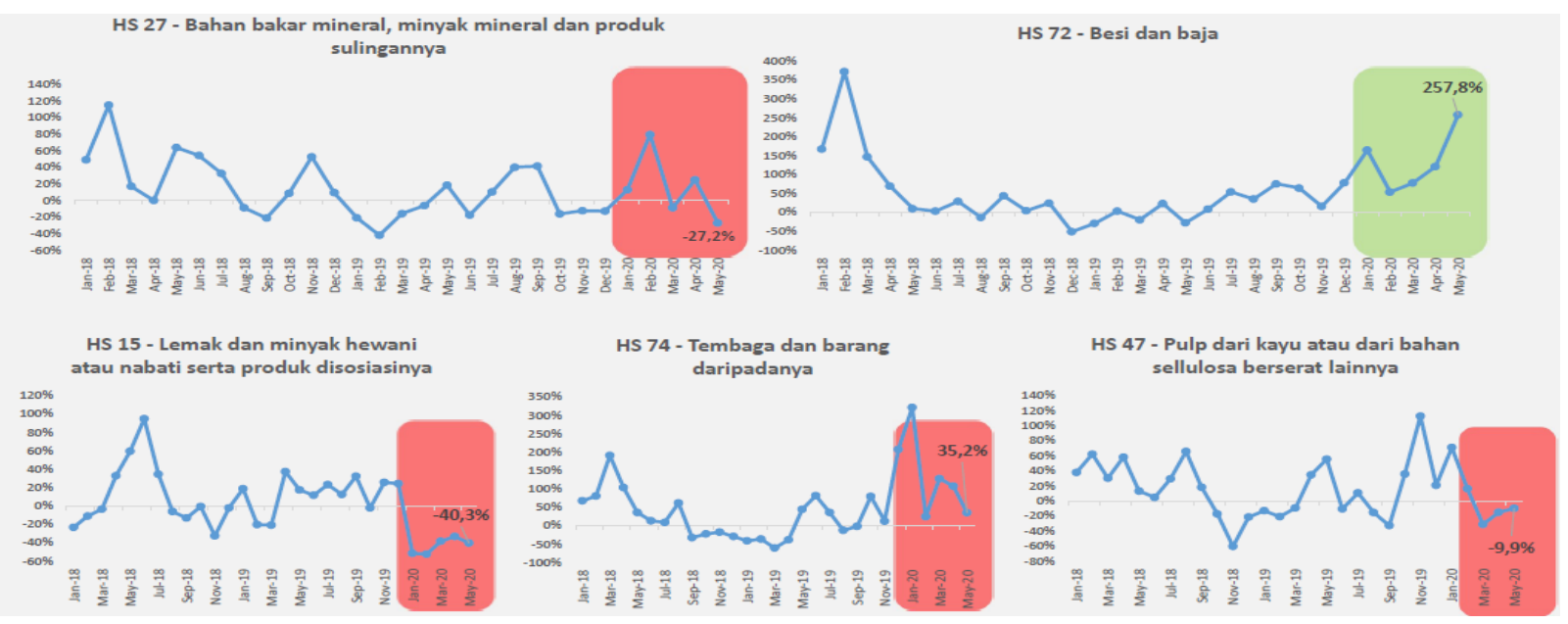

Gambar 4. Perkembangan Ekspor Pada Beberapa Sektor Ekonomi.

Sumber : Badan Pusat Statistik/ BPS (2020)

Berdasarkan gambar 4, ekspor golongan bahan bakar mineral pada triwulan I tahun 2020 tumbuh 0,7 persen secara QtQ. Namun secara YoY mengalami penurunan sebesar 3,6 persen akibat harga batu bara dunia yang turun tajam hingga mencapai -30,4 persen (YoY). Pertumbuhan ekspor golongan lemak dan minyak hewan/nabati mencatat pola sebaliknya, yaitu turun 8,1 persen secara QtQ namun tumbuh 10,8 persen secara YoY. Pertumbuhan ekspor golongan ini lebih didorong oleh faktor kenaikan harga minyak sawit dunia yang mencapai 25,6 persen (YoY), karena dari sisi volume mengalami penurunan sebesar 14,9 persen (YoY). Berdasarkan laporan (Kemenkeu, Kebijakan Fiskal Pemerintah Yang Pruden Dalam Menghadapi Pandemi, 2020) sektor tembaga ini terjadi perlambatan aktifitas yang mana pada akhirnya menimbulkan kontraksi yang cukup dalam pada pertumbuhan perpajakan perdagangan internasional. Dimana penyebab lainnya ialah karena turunnya volume impor, penurunan harga komoditas. Pandemi ini membuat perekonomian melemah dan sektor ekspor pun terdampak. Dikarenakan adanya kebijakan ekspor dan permintaan pasar yang menurun, sehingga hasil ekspor hasil hutan turun di semester I-2020. Namun mulai rebound kembali di paruh kedua tahun ini. Beberapa produk utama seperti furnitur, panel, pulp , kertas dan woodworking di bulan Juni 2020 mengalami peningkatan meski tipis/ belum signifikan (Rahayu \& Perwitasari, 2020). Pada kuartal I 2020 volume ekspor mengalami kenaikan cukup signifikan, yaitu sebanyak 498 ribu ton atau naik $27 \%$ jika dibandingkan periode yang sama tahun 2019. Pada periode bulan Januari-April 2019, volume ekspor besi baja sebesar 1,8 juta ton sedangkan pada periode yang sama tahun 2020 adalah 2,3 juta ton. kenaikan ekspor terbesar pada periode Januari - April 2020 terjadi pada produk jenis iron \& alloy yang meningkat dari 430 ribu ton menjadi 978 ribu ton atau naik sebesar 127\% dibandingkan periode yang sama tahun 2019 (IISIA, 2020). 
Anggaran pemerintah juga dialokasikan lebih dari IDR50 triliun merupakan salah satu potensi dari sisi infrastruktur, selain itu resiko volatilitas masih tinggi terutama jika dikaitkan dengan penanganan Covid-19 dan pertumbuhan kredit nasional diprediksikan di 1,7\% di tahun 2020.

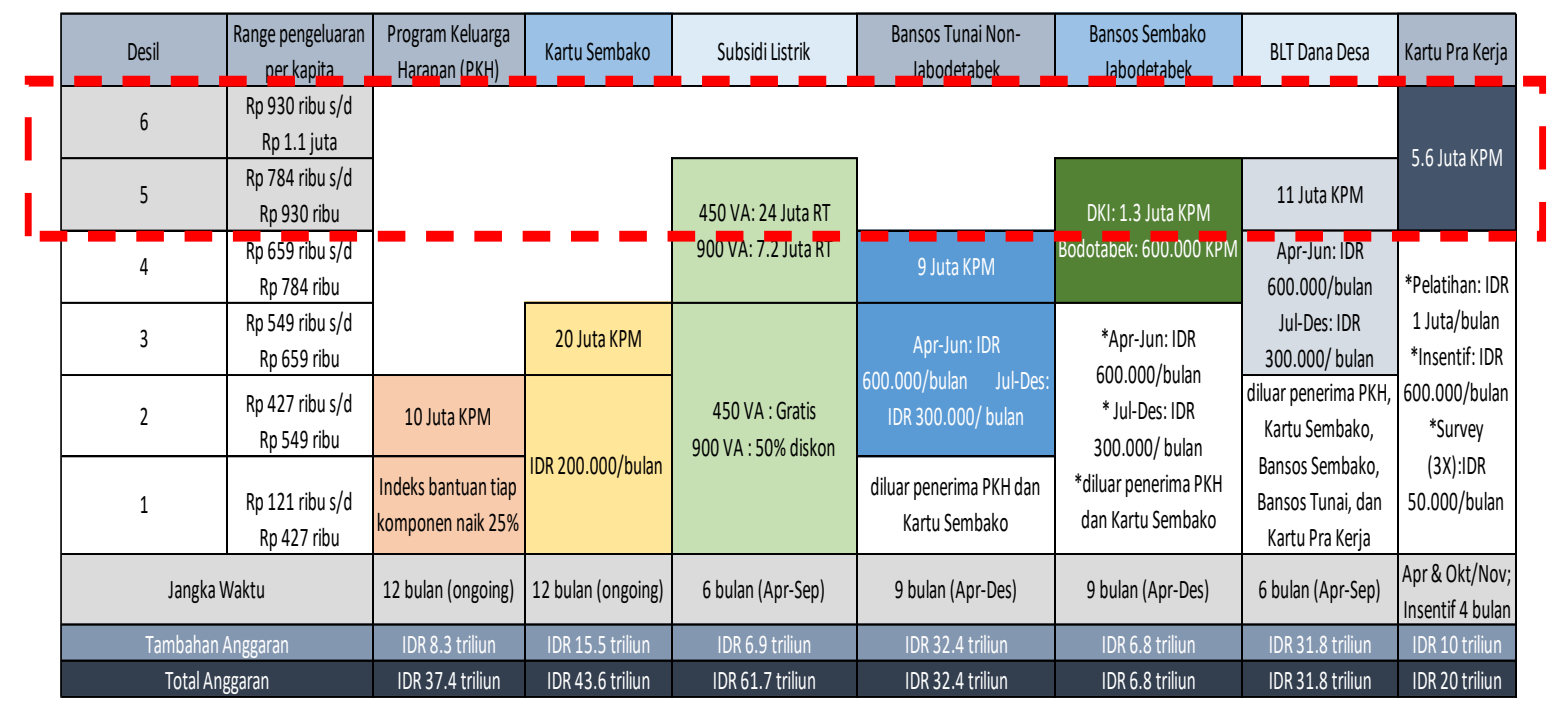

\section{Gambar 5. Bantuan Sosial Dari Pemerintah}

Sumber : Badan Pusat Statistik/ BPS (2002)

Saat ini pemerintah memberikan bantuan sosial kepada masyarat khususnya bagi masyarakat yang terdampak Covid-19.

\section{Program Keluarga Harapan (PKH)}

PKH adalah program pemberian bantuan sosial bersyarat kepada Keluarga Miskin (KM) yang ditetapkan sebagai keluarga penerima manfaat PKH. Bansos PKH ini diberikan sebulan sekali dari yjoglang sebelumnya empat kali dalam setahun, untuk mengantisipasi dampak wabah Covid-19 terhadap Keluarga Penerima Manfaat (KPM) PKH. (Hakim, 2020)

\section{Kartu Prakerja}

Kartu Prakerja ini diberikan kepada mereka yang terkena PHK,Pengangguran dan untuk mereka yang baru saja lulus dari pendidikan formal. Total, dana sebesar Rp 3.550.000 per orang akan ditransfer ke rekening bank atau rekening dompet elektronik seperti OVO, Link Aja, atau GoPay milik peserta. (Mardiyah \& Nurwati)

3. Kartu Sembako

Bantuan sosial berupa paket sembako dikucurkan sejak awal pandemi Covid-19 terjadi di Indonesia pada Maret. Jumlah besarannya sama, yakni Rp 600.000 per bulan selama 3 bulan. Total angarannya Rp 1 triliun rupiah. Namun pemerintah memperpanjang program ini sampai Desember, yang nilainya berkurang menjadi Rp 300.000 per bulan. 


\section{Subsidi Listrik}

Insentif ini berupa pembebasan tagihan, diskon listrik, penghapusan biaya minimum, dan penghapusan abonemen. Selain memperluas jangkauan pelanggan, periode pemberian insentif diperpanjang hingga Desember 2020. Pelanggan yang mendapatkan subsidi listrik yakni pelanggan $450 \mathrm{VA}$, dan $900 \mathrm{VA}$ subsidi. Keringanan tagihan listrik kemudian diperluas untuk usaha UMKM, yakini 900 VA bisnis dan 900 VA industri. Awalnya, listrik gratis berlaku untuk 3 bulan, namun kemudian diperpanjang hingga akhir tahun.

\section{BLT Dana Desa}

BLT Dana Desa disalurkan dalam dua gelombang. Masing-masing gelombang terdiri dari tiga tahapan. Gelombang pertama diberikan pada bulan April (tahap I), Mei (tahap II), dan Juni (tahap (III). Per bulannya, masing-masing keluarga penerima manfaat (KPM) akan mendapatkan bantuan sebesar Rp 600.000. Sementara itu, gelombang kedua diberikan pada bulan Juli (tahap IV), Agustus (tahap V), dan September (tahap VI). Jumlah bantuan yang diterima lebih rendah yakni Rp 300.000 per bulannya (Ihsanuddin, 2020).

Pemerintah harus menentukan skala prioritas dengan mengurutkan anggaran belanja berdasarkan tingkat urgensinya. Pemerintah dapat juga melakukan pemangkasan pada belanjabelanja tertentu misalnya pengeluaran untuk perjalanan dinas, belanja rapat, bimbingan teknis, penyuluhan, dan sejenisnya untuk dialihkan pada penanganan Covid-19 yaitu biaya perjalanan dinas, biaya belanja modal (Ginting \& Silalahi, 2020).

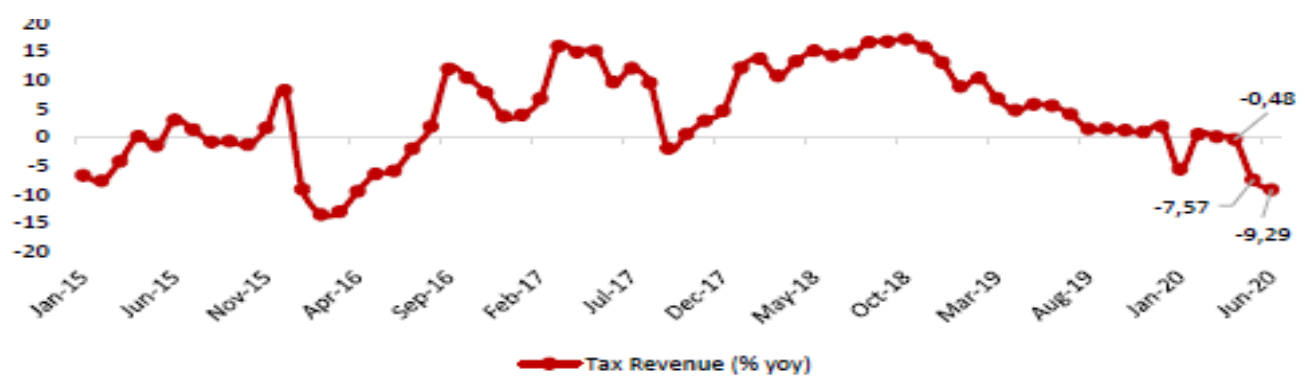

Gambar 6. Pengeluaran pemerintah tahun 2015-2020 Q2

Sumber: Bank Syariah (2020)

Penerimaan pajak turun akibat kondisi ekonomi melemah, dukungan insentif pajak dan penurunan tarif pajak penghasilan $(\mathrm{PPh})$. Seiring adanya aturan terkait Work From Home(WFH) baik untuk sektor pemerintah maupun sektor swasta, maka mulai terjadi perlambatan kegiatan usaha di akhir bulan Maret 2020 yang berpotensi menurunkan penyerahan dalam negeri yang kemudian akan menekan penerimaan Pajak Pertambahan Nilai Dalam Negeri (PPN DN) di bulan April 2020. Seperti yang kita lihat dari data diatas, penerimaan pajak memiliki presentase yang negatif pada bulan April (-0.48\%), Mei (-7.57\%), dan Juni (-9.29\%). Hal ini 
dikarenakan sejak pertengahan Maret, Sri Mulyani mulai merelaksasi PPh pasal 21 dan 22 bagi karyawan industri manufaktur. Relaksasinya hampir 100\% selama enam bulan. Lalu, ada pula pemotongan 30\% PPh pasal 25 untuk korporasi, dan restitusi PPN, selanjutnya pemerintah kembali menambah 11 sektor tambahan relaksasi pajak sejak April, terjadi penambahan diskon pembayaran $\mathrm{PPh}$ pasal 25 dari 30\% menjadi 50\%. Hal ini pula yang memberikan kontraksi yang dalam pada peneriman PPh pasal 25 ini. Pada kuartal I 2020, penerimaan PPh badan tercatat minus 13,56\%. Puncaknya terjadi pada Mei 2020, kontraksi mencapai minus 53,9\% (Tobing, 2020).

Pemerintah telah mengalokasikan dana sebesar Rp 695,19 triliun untuk penanganan Covid19 dan pemulihan ekonomi nasional. Anggaran Rp 695,19 triliun tersebut, dibagi menjadi enam fokus program anggaran. Dari enam fokus program anggaran alokasi anggaran dibagi untuk dua program di bidang kesehatan dan empat program di bidang ekonomi. Dari enam fokus program anggaran alokasi anggaran dibagi untuk dua program di bidang kesehatan dan empat program di bidang ekonomi. Dua program yang menjadi fokus bidang kesehatan adalah program kesehatan untuk penanganan Covid-19 dengan besaran anggaran $\mathrm{Rp}$ 87,55 triliun dan program insentif usaha dengan pagu anggaran sebesar Rp 120,6 triliun. Sedangkan empat program yang menjadi fokus Satgas Pemulihan dan Transformasi Ekonomi Nasional adalah program perlindungan sosial 203,9 triliun, Program UMKM sebesar Rp 123,47 triliun, program sektoral kementerian/lembaga dan Pemda sebesar Rp 106,1 triliun dan program pembiayaan korporasi sebesar Rp 53,57 triliun (Tambun, 2020).

Di sisi otomotif (gambar 7), pandemi memaksa produsen-produsen otomotif di berbagai belahan dunia untuk menutup fasilitas produksinya. Di saat yang sama, permintaan terhadap otomotif anjlok tajam seiring melemahnya daya beli masyarakat Januari 2020 angka penjualan retail masih mencapai 81.063 unit, Februari turun menjadi 77.847 unit, Maret turun lagi menjadi 60.448 unit. Untuk April, angka penjualan anjlok tajam hingga 60\% menjadi hanya 24.276 unit (Pramisti, 2020). Hal sama pun terjadi pada sektor alat berat, produksi alat berat nasional sepanjang semester I-2020 turun hingga 62\% menjadi 1.600 unit dibanding periode sama tahun lalu. Menurut penjualan pada alat berat Komatsu, sepanjang paruh pertama 2020 penjualan alat berat tersebut turun 55,50\% menjadi 853 unit dari sebelumnya 1.917 unit. Penurunan penjualan merata di semua sektor, dengan koreksi tertinggi terjadi di sektor pertambangan (Fitriani, 2020).

Hal berbeda yang terjadi pada bisnis property, dimana angka pertumbuhan menunjukkan nilai persentase yang menurun namun nilai tersebut masih tergolong aman disaat pandemi ini. Hal ini dikarenakan adanya sejumlah bank yang terus mendorong penyaluran kredit perumahan, salah satunya adalah PT Bank Tabungan Negara (Persero) Tbk (Richard, 2020). 


\begin{tabular}{|c|c|c|c|c|c|c|c|c|c|}
\hline \multirow{2}{*}{ Sector } & \multirow{2}{*}{ Indicator } & \multicolumn{7}{|c|}{ Growth (\%YoY) } & \multirow{2}{*}{$\begin{array}{l}\text { Growth May-20 } \\
\text { (\%MoM) }\end{array}$} \\
\hline & & 5M20 & $5 M 19$ & May-20 & Apr-20 & May-19 & 2019 & 2018 & \\
\hline Retail $^{1}$ & Ace Hardware sales (IDR) & -6.2 & 21.2 & -18.4 & -32.5 & 20.7 & 13.0 & 23.3 & 32.8 \\
\hline \multirow{4}{*}{ Automotive $^{2}$} & Total car sales (Unit) & -41.2 & -14.6 & -95.8 & -90.6 & -16.3 & -10.5 & 6.7 & -54.9 \\
\hline & Commercial vehicle (Unit) & -40.4 & -17.0 & -91.8 & -87.6 & -15.7 & -11.6 & 17.6 & -30.1 \\
\hline & Passenger vehicle (Unit) & -41.5 & -13.9 & -96.8 & -91.3 & -16.5 & -10.2 & 3.6 & -63.2 \\
\hline & Total motorcycle sales (Unit) & -39.6 & 8.1 & -96.1 & -79.3 & -4.7 & 1.6 & 8.4 & -82.3 \\
\hline \multirow{3}{*}{ Property ${ }^{3}$} & Housing Credit (IDR) & 2,327 a) & $7,884^{b)}$ & 6.4 c) & $7.3^{d)}$ & 12.9 e) & 7.8 & 13.3 & $\left.0.5^{c}\right)$ \\
\hline & Apartment Credit (IDR) & $257^{\text {a) }}$ & $578^{b)}$ & 10.1 c) & $11.8^{\mathrm{d})}$ & $22.0^{e)}$ & 12.0 & 29.0 & $0.2^{c)}$ \\
\hline & Total & $2,584^{\text {a) }}$ & $8,462^{b)}$ & $\left.6.6^{c}\right)$ & $7.5^{d)}$ & $13.2^{\mathrm{e})}$ & 8.0 & 13.9 & $0.4^{c)}$ \\
\hline Cement $^{4}$ & Total sales (Ton) & -11.9 & -3.9 & -38.3 & -6.3 & -8.4 & 0.3 & 4.8 & -28.9 \\
\hline \multirow{5}{*}{ Heavy Equipment ${ }^{5}$} & Total sales (Unit) & $-55,1$ & $-17,5$ & $-79,2$ & $-61,7$ & $-34,5$ & $-40,0$ & 28,8 & $-40,0$ \\
\hline & Agro segment (Unit) & $-60,5$ & $-25,5$ & $-74,6$ & $-119,8$ & $-43,8$ & $-55,0$ & 28,2 & $-30,5$ \\
\hline & Construction segment (Unit) & $-53,2$ & 3,7 & $-70,9$ & $-58,5$ & $-6,4$ & $-22,4$ & 29,6 & $-3,1$ \\
\hline & Forestry segment (Unit) & $-13,3$ & 21,2 & $-94,8$ & $-40,8$ & $-12,6$ & 1,8 & 9,2 & $-89,4$ \\
\hline & Mining segment (Unit) & $-65,5$ & $-29,4$ & $-82,9$ & $-70,3$ & $-46,5$ & $-51,6$ & 33,0 & $-47,9$ \\
\hline
\end{tabular}

\section{Gambar 1. Dampak Pandemi Covid-19 Terhadap Sektor Retail}

Sumber: Badan Pusat Statistik/ BPS (2020)

\section{Simpulan}

Coronaviruses (Cov) adalah virus yang menginfeksi sistem pernapasan. Penyebaran virus Corona ini sangat cepat sehingga penyebaran virus Corona telah meluas ke berbagai belahan dunia. Setiap negara pun melakukan upaya dalam memerangi pandemi dengan melakukan pembatasan orang masuk dan keluar dari wilayah yang terindikasi mengalami wabah covid-19. Tantangan yang perlu dihadapi saat ini adalah terkait perlambatan ekonomi yang bahkan hal ini terjadi di sejumlah negara, salah satunya Indonesia. Perlambatan ekonomi ini terjadi dikarenakan adanya beberapa sektor perekonomian yang melakukan pemberhentian aktivitas usaha karena diterapkannya Pembatasan Sosial Berskala Besar (PSBB). Hal ini berdampak pada berkontraksinya perdagangan internasional, bisnis retail, manufaktur, investasi, hingga sampai peningkatan pengangguran terbuka. Upaya pemulihan ekonomi tersebut ialah adanya pemulihan ekonomi nasional yang terdapat enam program yaitu pendanaan dalam penanganan Covid-19, program insentif usaha, perlindungan sosial, UMKM, padat karya (istilah yang mudah dipahami untuk program sektoral kementerian/lembaga dan pemda), serta pembiayaan korporasi.

\section{Daftar Pustaka}

Amadeo, K. (2020). How It's Measured and What Are The Causes. The Balance.

BI. (2020). Survei Konsumen Juli 2020 : Keyakinan Konsumen Terus Membaik. bi.go.id.

Buchori, A., \& Fardaniah, R. (2020). Kinerja Industri Pengolahan Triwulan III 2020 Membaik Pada Fase Kontraksi. Retrived from https://www.antaranews.com/berita/1782449/bikinerja-industri-pengolahan-triwulan-iii-membaik-meski-kontraksi

Effendi, S. (2020). Pandemi dan Disrupsi Perdagangan Internasional. Retrived from https://katadata.co.id/redaksi/indepth/5ed1ef9a32fe9/pandemi-dan-disrupsi-perdaganganinternasional 
Fitriani, E. (2020). Semester I, Produksi Alat Berat Anjlok 62\%. Retrived from https://investor.id/business/semester-i-produksi-alat-berat-anjlok-62

Ginting, R. R., \& Silalahi, D. E. (2020). Strategi Kebijakan Fiskal Pemerintah Indonesia dalam Menghadapi Pandemi COVID-19. Jurnal Ekonomi \& Ekonomi Syariah. doi:https://doi.org/10.36778/jesya.v3i2.193

Hakim, R. N. (2020). Antisipasi Dampak Pandemi, Bansos PKH Diberikan Sebulan Sekali Hingga Desember. Retrived from https://nasional.kompas.com/read/2020/04/08/12181141/antisipasi-dampak-pandemibansos-pkh-diberikan-sebulan-sekali-hingga?page=all

Hanoatubun, S. (2020). Dampak Covid - 19 terhadap Prekonomian Indonesia. EduPsyCouns: Journal of Education, Psychology and Counseling. Von Retrieved from https://ummaspul.ejournal.id/Edupsycouns/article/view/423

Ihsanuddin. (2020). Ada 7 Bantuan Pemerintah Selama Pandemi Covid-19, Berikut Rinciannya... kompas.com

IISIA. (2020). Ekspor Besi Baja Meningkat di Tengah Pandemi COVID-19. Indonesia Iron \& Steel Industry Association.

Indayani, S., \& Hartono, B. (2020). Analisis Pengangguran dan Pertumbuhan Ekonomisebagai Akibat Pandemi Covid-19. Jurnal Ekonomi \& Manajemen Universitas Bina Sarana Informatika.

Kemenkeu. (2020). Kebijakan Fiskal Pemerintah Yang Pruden Dalam Menghadapi Pandemi. Retrived from https://www.kemenkeu.go.id/publikasi/siaran-pers/siaran-pers-kebijakanfiskal-pemerintah-yang-pruden-dalam-menghadapi-pandemi/

Kumala, R., \& Junaidi, A. (2020). Strategi Bisnis Dan Pemanfaatan Kebijakan Pajak Di Masa Pandemi COVID-19 Dan Era New Normal (Studi Kasus Pelaku UKM Marketplace). Prosiding Seminar Stiami.

Lubis, M. W. (2020, Juli 14). Pertumbuhan Ekonomi Inggris pada Mei Lebih Rendah dari Prediksi. Retrived from https://kabar24.bisnis.com/read/20200714/19/1265803/pertumbuhanekonomi-inggris-pada-mei-lebih-rendah-dari-prediksi

Mardiyah, R. A., \& Nurwati, R. N. (kein Datum). Dampak Pandemi Covid-19 Terhadap Peningkatan Angka Pengangguran Di Indonesia.

Novika, S. (2020). Emas Apa yang Paling Banyak Diincar Saat Pandemi? Retrived from https://finance.detik.com/berita-ekonomi-bisnis/d-5179877/emas-apa-yang-paling-banyakdiincar-saat-pandemi

Pramisti, N. Q. (2020). Pukulan Berat Industri Otomotif Akibat Pandemi COVID-19. Retrived from https://tirto.id/pukulan-berat-industri-otomotif-akibat-pandemi-covid-19-fAU7

Purnomo, H. (2020). Batu Bara Hingga Nikel Keok, Hanya CPO yang Berjaya! Retrived from https://www.cnbcindonesia.com/market/20200420092755-17-153013/batu-bara-hingganikel-keok-hanya-cpo-yang-berjaya

Rahayu, A. C., \& Perwitasari, A. S. (2020). Ini Penyebab Ekspor Produk Kehutanan Indonesia Ke Uni Eropa Kurang Maksimal. Retrived from https://industri.kontan.co.id/news/inipenyebab-ekspor-produk-kehutanan-indonesia-ke-uni-eropa-kurang-maksimal

Richard, T. (2020). Apakah Bisnis Properti Masih Bisa Bangkit di Masa Pandemi Covid-19? Ini Jawabannya! 99.co.

Tambun, L. T. (2020). Ini Empat Fokus Satgas Pemulihan dan Transformasi Ekonomi Nasional. Retrived from https://www.beritasatu.com/nasional/663269/ini-empat-fokus-satgaspemulihan-dan-transformasi-ekonomi-nasional

Thomas, V. F. (August 2020). Pertumbuhan Ekonomi RI Q2 2020 Minus 5,32\%, Terburuk Sejak 1999. Retrived from https://tirto.id/pertumbuhan-ekonomi-ri-q2-2020-minus-532-terburuksejak-1999-fVQK 
Tobing, S. (2020). Rapor Merah Penerimaan Pajak dan Siasat Pemerintah Mengatasinya. Retrived from https://katadata.co.id/sortatobing/finansial/5f44be08d74c2/rapor-merahpenerimaan-pajak-dan-siasat-pemerintah-mengatasinya

WHO. (2020). Corona disesase (COVID-19) Weekly Epidemiological Update and Weekly Operational Update. Retrived from https://www.who.int/emergencies/diseases/novelcoronavirus-2019/situation-reports

Yunianto, T. K. (2020). Tertekan Daya Beli, Bisnis Retail Kuartal II Diramal Tumbuh Minus 3\%. Retrived from https://katadata.co.id/ekarina/berita/5f2a1be2c9e13/tertekan-daya-beli-bisnisretail-kuartal-ii-diramal-tumbuh-minus-3 